\title{
Kajian Perilaku Masyarakat Pesisir yang Mengakibatkan Kerusakan Lingkungan (Studi Kasus di Pantai Kuwaru, Desa Poncosari, Kecamatan Srandakan, Kabupaten Bantul, Provinsi DIY)
}

\author{
Zulmiro Pinto ${ }^{1}$ \\ Universidade Oriental de Timor Lorosa'e \\ Dili, Timor Leste \\ Artikel Masuk : 7 September 2015 \\ Artikel Diterima : 29 Oktober 2015 \\ Tersedia Online : 30 Desember 2015
}

\begin{abstract}
Abstrak: Wilayah pesisir merupakan daerah peralihan laut dan daratan. Pengembangan wilayah pesisir seringkali mendapatkan tekanan dari berbagai aktivitas manusia dan fenomena yang terjadi di darat maupun laut. Hal ini terilustrasi di Pantai Kuwaru, Kabupaten Bantul. Pantai Kuwaru memiliki keunikan alam dibandingkan dengan pantai lainnya terutama dengan adanya pohon cemara udang yang rindang dan warung kuliner yang murah sehingga menarik wisatawan untuk berkunjung. Keindahan alam yang ada di Pantai Kuwaru saat ini telah rusak akibat perilaku masyarakat yang menebang pohon cemara udang. Tujuan penelitian ini untuk mengkaji perilaku masyarakat pesisir yang mengakibatkan kerusakan lingkungan dan berdampak pada aspek sosial dan ekonomi masyarakat. Penelitian ini menggunakan metode campuran (mixed methods) yang dilakukan dengan analisis sequential explanatory design. Pemilihan sampel dilakukan dengan purposive sampling dengan informan pemerintah dan kelompok nelayan. Hasil penelitian menunjukkan bahwa perilaku masyarakat pesisir yang berpengaruh terhadap kerusakan lingkungan. Hal ini juga dipengaruhi oleh faktor rendahnya tingkat pendidikan masyarakat tentang wilayah pesisir Pantai Kuwaru. Pemerintah hendaknya dapat bekerjasama dengan masyarakat untuk menyelamatkan Pantai Kuwaru dari kerusakan lingkungan yang diakibatkan oleh perilaku masyarakat.
\end{abstract}

Kata kunci: kerusakan lingkungan, masyarakat pesisir, perilaku

\begin{abstract}
Coastal area is a transition area between sea and land. Coastal area development is influenced by the pressures of human activities occupying both areas. The condition is illustrated in Kuwaru Beach, Bantul District. Kuwaru Beach has a unique nature formed by pine tree lines and cheap culinary stalls around. However, the human behavior might have endangered its preservation due to illegal logging. The aim of this study was to examine the behavior of coastal communities associated with the environmental damage in KuwaruBeach and its impact on social and economic livelihood. A mixed method was applied by using sequential explanatory design. Selection of the sample was completed by purposive sampling on government and fishermen groups. The results showed that the behavior of the coastal
\end{abstract}

\footnotetext{
${ }^{1}$ Korespondensi Penulis: Universidade Oriental de Timor Lorosa'e, Dili, Timor Leste Email: pintoayu@gmail.com
} 


\section{Kajian Perilaku Masyarakat Pesisir yang Mengakibatkan Kerusakan Lingkungan...}

communities has to lead to the environmental degradation. This research also found that the people's behavior is really influenced by the low education level and low awareness of the coastal region of Kuwaru Beach. The local government should work together with the local communities to conserve Kuwaru Beach from the man made environmental damage.

Keywords: environmental damage, coastal communities, behavior

\section{Pendahuluan}

Wilayah pesisir merupakan daerah peralihan laut dan daratan. Kondisi tersebut menyebabkan wilayah pesisir mendapatkan tekanan dari berbagai aktivitas dan fenomena di darat maupun di laut. Fenomena yang terjadi di daratan antara lain abrasi, banjir dan aktivitas yang dilakukan oleh masyarakat yaitu pembangunan permukiman, pembabatan hutan untuk persawahan, pembangunan tambak dan sebagai yang pada akhirnya memberi dampak pada ekosistem pantai. Demikian pula fenomena-fenomena di laut, seperti pasang surut air laut, gelombang badai dan sebagainya (Hastuti, 2012). Faktor alam lainnya yang juga menyebabkan kerusakan lingkungan adalah gempa dan gelombang tsunami dikarenakan rusaknya ekosistem pesisir sehingga tidak ada penghalang sebagai peredam gelombang tsunami (Arifin, 2005).

Secara umum, aktivitas masyarakat pesisir meliputi aktivitas ekonomi berupa kegiatan perikanan yang memanfaatkan lahan darat, lahan air, dan laut terbuka; kegiatan pariwisata dan rekreasi yang memanfaatkan lahan darat, lahan air, dan objek di bawah air; kegiatan transportasi laut yang memanfaatkan lahan darat dan alokasi ruang di laut untuk jalur pelayaran, kolam pelabuhan dan lain-lain; kegiatan indutri yang memanfaatkan lahan darat; kegiatan pertambangan yang memanfaatkan lahan darat dan laut; kegiatan pembangkit energi yang menggunakan lahan darat dan laut; kegiatan industri maritim yang memanfaatkan lahan darat dan laut, pemukiman yang memanfaatkan lahan darat untuk perumahan dan fasilitas pelayanan umum; dan kegiatan pertanian dan kehutanan yang memanfaatkan lahan darat. Aktivitas ekonomi yang dilakukan bertujuan untuk meningkatkan kesejahteraan masyarakat dengan ketergantungannya terhadap kondisi lingkungan dan sumber daya alam yang ada di sekitarnya, pemerintah dalam pengelolaan lingkungan hidup dan sumberdaya alam, lembaga sosial aktivitas, ekonomi pendidikan, kesehatan dan lain-lain (Bengen, 2002). Namun demikian, setiap aktivitas dan perilaku manusia berpengaruh terhadap lingkungan.

Setiap manusia memiliki perilaku yang berbeda tergantung dari bagaimana manusia atau individu berinteraksi dengan lingkungannya. Dalam kaitannya dengan lingungan hidup, perilaku manusia dapat menentukan keberlanjutan kondisi lingkungan. Perilaku pengelolaan lingkungan hidup bertujuan untuk memenuhi kebutuhan hidup saat ini tanpa merusak atau menurunkan kemampuan generasi mendatang untuk memenuhi kebutuhan hidupnya. Kerangka pendekatan yang digunakan dalam pengelolaan lingkungan hidup adalah pendekatan keterpaduan dalam mengoptimalkan pemanfaatan sumber daya pesisir dan lautan. Zamlawi (1997) menyatakan bahwa pengelolaan lingkungan hidup adalah suatu upaya terpadu untuk melestarikan fungsi lingkungan hidup, meliputi (1) penataan, (2) pemanfaatan, (3) pemulihan, (4) pengawasan, dan (5) pengendalian yang terus menerus dilakukan untuk pelestarian keseimbangan ekologi lingkungan. Keseimbangan ekologi akan menjamin tercapainya keberhasilan pembangunan yang berkelanjutan.

Berbagai masalah lingkungan berkaitan dengan pengetahuan, sikap, perilaku dan penilaian manusia terhadap lingkungan. Hasil penelitian Harris (2006) tentang kondisi lingkungan di Cina menunjukkan bahwa tingkat pendidikan dan pengetahuan, gaya hidup, dan persepsi orang terhadap seberapa berharganya lingkungan menentukan perilaku 
manusia terhadap lingkungan. Lebih lanjut, kurangnya kesadaran dan pemahaman masyarakat tentang kebijakan kepesisiran, tingkat pendidikan masyarakat yang rendah, watak masyarakat, serta tekanan biaya hidup menyebabkan masyarakat pesisir sering melakukan perusakan lingkungan pesisir (Primyastanto, Dewi, \& Susilo, 2010). Hal ini diperkuat bahwa kerusakan pesisir lebih dipengaruhi oleh faktor alam dan manusia (Vatria, 2010; Gumilar, 2012). Hiariey \& Romeon (2013) menambahkan bahwa tingkat pendidikan, persepsi, dan pendapatan mempengaruhi kepentingan terhadap pemanfaatan wilayah pesisir. Pengaruh pendapat masyarakat terhadap lingkungan merupakan bagian dari mekanisme yang menghasilkan perilaku yang nyata dari masyarakat itu sendiri dalam menciptakan perubahan lingkungan (Heddy, 1994).

Aktivitas pariwisata di wilayah pesisir potensial dikembangkan baik terkait wisata alam maupun buatan. Namun demikian, wilayah pesisir merupakan wilayah yang rentan mengalami kerusakan akibat aktivitas pariwisata wisata. Hall (2001) dan Zahedi (2008) mengungkapkan bahwa pariwisata pesisir menjadi jenis pariwisata yang paling berkembang di berbagai belahan dunia namun memiliki peluang dampak kerusakan lingkungan yang lebih besar pula menyangkut berbagai atraksi dan destinasi yang mampu mengubah karakteristik kepesisiran. Pariwisata hanya berprioritas pada keuntungan secara ekonomi bukan lingkungan sehingga perlu ada pembinaan terhadap masyarakat lokal tentang bagaimana mengelola wisata agar berkelanjutan terhadap lingkungan (Walpole \& Goodwin, 2001; Zahedi, 2008). Ini menunjukkan bahwa aktivitas pariwisata dan lingkungan saling terkait karena melibatkan banyak aktivitas wisata yang akan berdampak pada lingkungan, ekonomi, fisik, dan sosial (Shafei \& Mohamed, 2012; Rabbany, Afrin, Rahman, Islam, \& Hoque, 2013). Kurangnya pengelolaan wilayah pesisir, penggunaan sumber daya yang tidak tepat, kurangnya standar lingkungan, dan kurangnya keseimbangan antara aktivitas wisata dengan ruang fisik menyebabkan kerusakan wilayah pesisir akibat aktivitas wisata semakin parah (Shafei \& Mohamed, 2012). Hal ini akan berdampak pada kondisi perekonomian masyarakat yang menggantungkan pada sumber daya pesisir serta keberlanjutan wilayah pesisir.

Pantai Kuwaru sebagai lokasi penelitian terletak di Desa Poncosari, Kecamatan Srandakan, sekitar $40 \mathrm{~km}$ di selatan Kota Yogyakarta. Sebagai salah satu objek wisata pantai, Pantai Kuwaru memiliki keindahan alam yang tidak dapat ditemui pada pantaipantai lain di pesisir selatan Provinsi DIY. Pantai Kuwaru memiliki potensi cemara laut yang eksotis. Selain memiliki daya tarik wisata, pohon cemara udang di sekitar Pantai Kuwaru juga bermanfaat untuk menahan ombak pada saat tsunami. Keberadaan Pantai Kuwaru menjadi sumber mata pencaharian lain bagi para nelayan di dusun nelayan sekitarnya. Kelompok nelayan di Pantai Kuwaru yang telah lama berdiri menjadi peluang utama dalam menggali potensi pantai Kuwaru secara lebih luas dan humanis.

Meskipun memiliki potensi alam berupa cemara udang yang tidak terdapat di pantaipantai lainnya, perilaku masyarakat pesisir sekitar Pantai Kuwaru, seperti menebang pohon cemara udang untuk membuat tambak, menyebabkan kerusakan lingkungan Pantai Kuwaru. Selain berdampak negatif pada lingkungan, hal ini juga berdampak pada sosial terkait dengan hilangnya mata pencaharian penduduk dan ekonomi, seperti menurunnya pendapatan karena secara tidak langsung akan berdampak pada menurunnya kunjungan wisatawan di Pantai Kuwaru. Padahal, potensi yang dimiliki oleh Pantai Kuwaru patut dilestarikan dan dikembangkan, baik oleh masyarakat setempat maupun pemerintah.

Berbagai studi mengenai perilaku masyarakat yang berakibat pada kerusakan lingkungan di wilayah pesisir cukup banyak telah dikaji. Guna memperkuat kajian yang telah ada, penelitian ini bertujuan untuk mengkaji perilaku masyarakat pesisir yang mengakibatkan kerusakan lingkungan dan berdampak pada aspek sosial dan ekonomi masyarakat. Pada bagian akhir penelitian juga ditunjukkan peran masing-masing stakeholder untuk meminimalisir dampak yang kerusakan lingkungan di Pantai Kuwaru. 


\section{Metode Penelitian}

Penelitian menggunakan metode penelitian campuran (mixed methods). Penelitian campuran adalah metode penelitian yang mengkombinasikan antara metode kuantitatif dan kualitatif agar diperoleh data yang lebih komprehensif, valid, reliabel, dan obyektif (Sugiyono, 2012). Melalui metode penelitian campuran tersebut, penelitian bertujuan untuk mengetahui kajian perilaku masyarakat pesisir di Pantai Kuwaru yang menyebabkan kerusakan lingkungan.

Pengumpulan data dilakukan menggunakan pengumpulan data primer melalui teknik wawancara, kuesioner dan observasi lapangan. Metode sampling yang digunakan adalah Purposive Sampling. Melalui metode sampling tersebut, peneliti memilih lima puluh responden masyarakat sekitar Pantai Kuwaru yang berkaitan langsung dengan lokasi penelitian dan mengetahui mengenai Pantai Kuwaru. Peneliti juga memilih lima responden dari instansi atau pemerintah yang mengetahui tentang Pantai Kuwaru, meliputi Dinas Perencanaan dan Pembangunan Daerah Kabupaten Bantul, Dinas Pariwisata Kabupaten Bantul, Badan Penanggulangan Bencana Daerah (BPBD) Kabupaten Bantul, dan tokoh masyarakat Desa Poncosari.

Analisis dilakukan dengan menggunakan metode analisis Sequential Explanatory Design. Melalui metode analisis tersebut, pada tahap pertama dilakukan pengumpulan data dan analisis data dengan kuantitatif. Lalu pada tahap kedua dilakukan pengumpulan data dan analisis data secara kualitatif untuk memperkuat hasil penelitian kuantitaif yang dilakukan di tahap pertama. Dengan metode analisis tersebut, peneliti berupaya untuk menjabarkan data dan informasi melalui uraian sistematis untuk mengetahui perilaku masyarakat pesisir yang mengakibatkan kerusakan lingkungan dan berdampak pada lingkungan, sosial, dan ekonomi. Selanjutnya dari kajian perilaku masyarakat tersebut dinilai baik buruknya perilaku masyarakat berdasarkan norma atau aturan yang ada di pesisir Pantai Kuwaru.

\section{Gambaran Umum Wilayah Studi}

Kabupaten Bantul memiliki banyak obyek wisata yang menjadi andalan dalam mengelola potensi Bantul sebagai upaya Pendapatan Asli Daerah (PAD), salah satunya adalah Pantai Kuwaru. Pantai Kuwaru merupakan salah satu pantai termuda di pantai selatan Kabupaten Bantul di antara Pantai Parangtritis, Pantai Depok, Pantai Pandansimo, Pantai Samas, Pantai Goa Cemara, dan Pantai Baru.

Secara administratif, Pantai Kuwaru terletak di Desa Poncosari tepatnya di Dusun Kuwaru. Dusun Kuwaru memiliki luas wilayah seluas $95.000 \mathrm{~km}^{2}$ dan terdiri 6 wilayah Rukun Tetangga (RT), yaitu RT 1, RT 2, RT 3, RT 4, RT 5 dan RT 6. Pemetaan secara geografis untuk keseluruhan Rukun Tetangga (RT) terletak di sepanjang jalan utama yang sudah diaspal atau sudah menggunakan konblok. Adapun batas wilayah Dusun Kwaru meliputi (lihat Gambar 1):

Sebelah Barat : Ngentak

Sebelah Utara : Dusun Karang

Sebelah Selatan : Samudera Indonesia

Sebelah Timur : Cangkring 


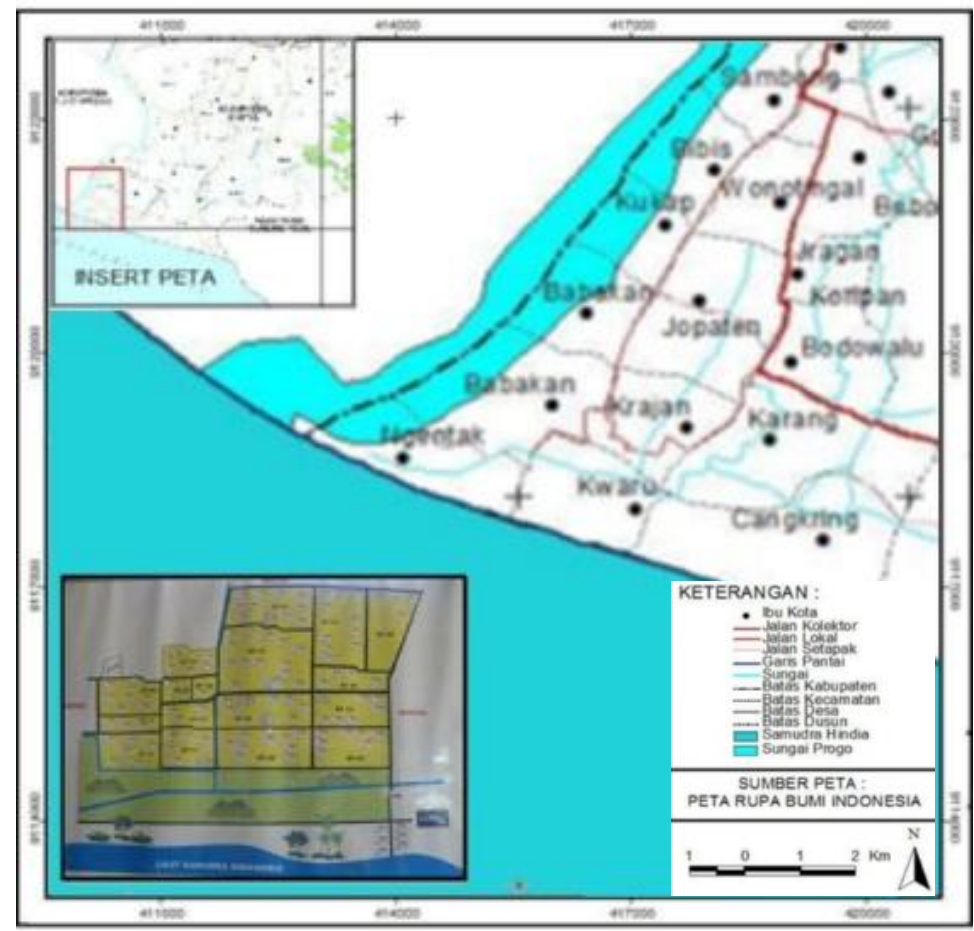

Gambar 1. Peta Lingkup Wilayah Studi

Berkembangnya Pantai Kuwaru sebagai salah satu objek wisata pantai selatan Yogyakarta tidak terlepas dari adanya pembangunan Jalur Jalan Lintas Selatan (JJLS) di wilayah Kabupaten Bantul yang saat ini sudah mencapai Pantai Pandansimo yang notabene terletak di sebelah barat Pantai Kuwaru. Dengan adanya pembangunan JJLS, perkembangan sektor wisata di Bantul dan perekonomian masyarakat semakin berkembang dimana memberi peluang munculnya usaha baru terkait dengan sektor pariwisata di kawasan pesisir Bantul karena selama ini usaha masyarakat masih terfokus di sektor wisata pantai dan pertanian.

Pantai Kuwaru adalah pantai yang cukup rawan terhadap bencana terutama gempa, tsunami dan abrasi karena terletak di bagian selatan Yogyakarta dan dikategorikan sebagai wilayah rawan bencana.Pantai Kuwaru merupakan daerah wisata bahari yang memiliki resiko tinggi terkena abrasi pantai dibandingkan pantai-pantai lain di bagian selatan Yogyakarta, seperti Pantai Parangtritis dan Pantai Pandansimo. Berdasarkan informasi dari tokoh masyarakat Dusun Kuwaru, telah terjadi abrasi sekitar 120 meter selama sekitar 20 tahun atau sekitar 6 meter per tahun. Adapun indikator lapangan yang menunjukkan abrasi adalah rumah sumur pompa yang tenggelam, jarak awal dari garis pantai saat dibangun sekitar 100 meter.

Pantai Kuwaru mempunyai potensi pada keindahan alamnya. Pada tahun 2012, jumlah wisatawan di Pantai Kuwaru mencapai 140.160 orang. Pantai Kuwaru memiliki kelebihan dengan adanya Pohon Cemara Udang yang ditanami oleh masyarakat, PT.INDOCOR dan Universitas Gadjah Mada (UGM). Pada tahun 1980, Pantai Kuwaru hanya memiliki tumbuhan pandan liar di pesisir pantai sehingga merusak semua lahan pertanian masyarakat. Kemudian, pada tahun 1994 pihak dari Tim Riset Unggulan Terpadu (RUT) menanam pohon di Pantai Samas. Pada tahun 2000 Fakultas Kehutanan Universitas Gadjah Madah bekerjasama dengan PT. INDOCOR menanam pohon cemara udang di 
dekat kawasan PT. INDOCOR. Pada tahun 2000 juga masyarakat mulai menanam pohon cemara udang di Pantai Kuwaru yang diinisiasi oleh kepala Dusun Kuwaru.

Pantai Kuwaru memiliki beberapa komoditas yang potensial dikembangkan menjadi komoditas pariwisata. Selain hasil laut dan vegetasi cemara laut, Pantai Kuwaru memiliki potensi akan keindahan alam pantai yang eksotis. Adapula wisata kuliner seafood dari hasil tangkapan para nelayan di Dusun Kuwaru. Aktivitas wisatawan di Pantai Kuwaru terlihat di Gambar 2.

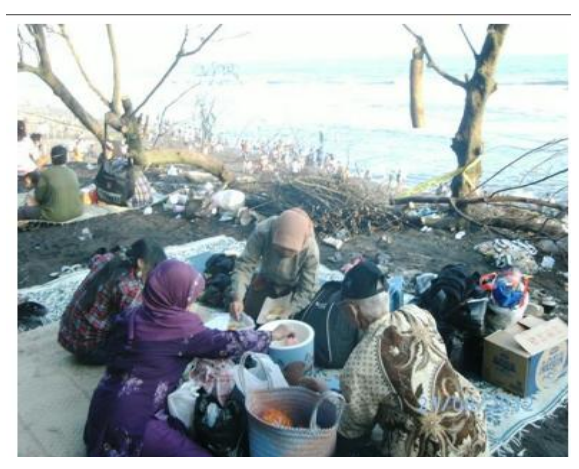

\section{Gambar 2. Aktivitas Wisatawan di Pantai Kuwaru}

\section{Hasil dan Pembahasan}

\section{Analisis Karakteristik Mata Pencaharian Masyarakat di Pantai Kuwaru}

\section{Analisis Karakteristik Petani di Sekitar Pantai Kuwaru}

Sebagian besar masyarakat Dusun Kuwaru bekerja di sektor pertanian. Namun, keberadaan tambak udang di sekitar Pantai Kuwaru mengganggu tanaman pertanian milik warga. Ini dikarenakan udara di sekitar tambak mengandung garam sehingga akan berpengaruh terhadap lahan pertanian di sekitarnya, dimana pertanian tidak dapat tumbuh. Tanaman warga, seperti padi dan palawija menjadi sulit tumbuh karena uap air yang mengandung garam. Dalam mengatasi masalah tersebut, belum ada upaya yang dilakukan oleh masyarakat sekitar.Sementara itu, pemerintah melalui Badan Perencanaan Daerah Pembangunan (BAPPEDA) telah melakukan negosiasi denga para petambak agar menutup tambak yang merusak lingkungan Pantai Kuwaru karena aktivitas tambak yang ada di pesisir pantai selatan dapat menganggu aktivitas pariwisata dan pertanian.

\section{Analisis Karakteristik Nelayan di Pantai Kuwaru}

Sebagian masyarakat di Pantai Kuwaru memiliki tambak udang. Usaha tambak udang di Pantai Kuwaru cukup menjanjikan karena hasil melaut yang tidak menentu akibat gelombang laut dan cuaca yang mempengaruhi hasil tangkapan. Setelah adanya salah seorang warga yang mencoba untuk berwirausaha dibidang tambak udang dan berhasil, maka petani dan nelayan di daerah Pantai Kuwaru mengambil alternatif lain untuk berwirausaha di bidang tambak udang. Banyak petani dan nelayan yang meminjam uang di bank untuk membangun kolam udang dan modal membeli benih udang. Namun, muncul permasalahan bahwa dalam upaya pembuatan kolam tambak udang harus menebang pohon cemara di sekitar pantai. Sebagai dampaknya, ancaman abrasi air laut semakin besar. 


\section{Analisis Kondisi Sosial Ekonomi Masyarakat Pesisir Pantai Kuwaru}

Masyarakat di Pantai Kuwaru mempunyai pekerjaan tetap dan sampingan dengan jumlah pendapatan yang bervariasi. Mata pencaharian utama masyarakat Pantai Kuwaru didominasi oleh kegiatan di sektor pertanian, mencakup pertanian tanaman pangan, perikanan dan peternakan. Pada tahun 2012, jumlah penduduk yang bekerja pada sektor pertanian sebesar 270 jiwa (61\%), nelayan sebesar 110 jiwa (24\%), jasa sebesar 110 jiwa (4\%), sektor perdagangan sebesar 60 jiwa (8\%) dan bangunan sebesar 7 jiwa (3\%). Mata pencaharian tertinggi adalah di sektor pertanian karena daerah pesisir Pantai Kuwaru sangat cocok untuk daerah pertanian.Disamping bekerja pada sektor pertanian, beberapa di antara penduduk juga bekerja di sektor pariwisata melalui jasa dan usaha terkait pariwisata, seperti usaha kuliner (40\%), usaha souvenir (16\%), warung kelontong (14\%), penyewaan tikar $(10 \%)$, dan usaha lainnya $(20 \%)$.

Jumlah pendapatan masyarakat Pantai Kuwaru bervariasi, yaitu kurang dari Rp 750.000,00 hingga lebih dari Rp 4.500.000,00. Persentase terbesar sebesar 30\% pendapatan masyarakat berada pada level Rp 751.000,00 hingga Rp 1.500.000,00. Kondisi pendapatan tergantung dari pekerjaan yang digeluti. Dari beberapa mata karakteristik masyarakat di Pantai Kuwaru sektor pariwisata juga sangat banyak karena berpeluang untuk mendapatkan pekerjaan dan pendapatan dari sektor pariwisata tersebut.

Jika dilihat dari tingkat pendidikan, pada tahun 2012, mayoritas dari penduduk hanya menempuh jenjang pendidikan SD, yaitu sebanyak 142 jiwa (33\%). Sementara itu, penduduk yang menempuh pendidikan ke jenjang akademi/PT sebesar 13 jiwa (3\%), Hal ini menunjukkan bahwa tingkat pendidikan penduduk di Pantai Kuwaru dikategorikan masih rendah. Tingkat pendidikan yang rendah menyebabkan perilaku masyarakat untuk menjaga lingkungan menjadi kurang dan berdampak pada lingkungan sosial dan ekonomi. Sebagian masyarakat di sekitar Pantai Kuwaru beranggapan bahwa keberadaan pohon cemara udang menyebabkan kerusakan lingkungan oleh abrasi menjadi meningkat. Padahal, menurut fungsinya pohon cemara udang adalah penting untuk wilayah pesisir.

\section{Analisis Perilaku dan Dampak Kerusakan Lingkungan Pantai Kuwaru}

Kerusakan lingkungan yang terjadi di Pantai Kuwaru disebabkan oleh perilaku masyarakat di sekitar pantai. Pantai Kuwaru pada awalnya telah dikembangkan oleh pemerintah melalui Dinas Pariwisata Kabupaten Bantul dengan program promosi Pantai Kuwaru keluar dari Kabupaten Bantul. Namun begitu, dalam perjalanannya muncul permasalahan bahwa terdapat sebagian masyarakat yang membagi tanah di pesisir Pantai Kuwaru menjadi beberapa petak untuk digunakan sebagai lahan tambak udang. Upaya pembukaan lahan baru untuk usaha tambak udang tersebut merusak lingkungan, dimana masyarakat menebang pohon cemara udang, pohon akasia, dan pohon leresidi yang telah ada di pesisir Pantai. Gambar 3 menunjukkan kondisi Pantai Kuwaru sebelum dan sesudah penebangan pohon cemara udang terjadi.

Hasil analisis kuesioner menunjukkan bahwa sebanyak 90\% responden menyatakan setuju dan 10\% responden menyatakan sangat setuju bahwa penebangan pohon cemara udang berdampak pada aktivitas ekonomi di Pantai Kuwaru. Kerusakan lingkungan menyebabkan penurunan pendapatan dari kegiatan wisata. Lebih lanjut, sebanyak $80 \%$ responden menyatakan setuju dan $20 \%$ responden menyatakan sangat setuju bahwa penebangan pohon cemara udang berdampak pada penurunan jumlah wisatawan. Pohon cemara udang adalah salah satu atraksi wisata di Pantai Kuwaru. Namun, setelah adanya penebangan pohon cemara udang menyebabkan udara di sekitar pantai menjadi panas dan kurang menarik minat wisatawan. Pada akhirnya, sebanyak 92\% responden menyatakan setuju dan $8 \%$ responden menyatakan sangat setuju bahwa keberadaan usaha tambak udang yang merusak pohon cemara udang mengakibatkan kerusakan lingkungan yang 
signifikan di Pantai Kuwaru. Hal ini dikarenakan hilangnya pohon cemara udang meningkatkan kondisi abrasi di Pantai Kuwaru. Sebagai akibatnya, beberapa jenis usaha tersebut terpaksa gulung tikar, terutama untuk para pengusaha warung kuliner. Kondisi ini menunjukkan bahwa kerusakan lingkungan di Pantai Kuwaru memberi dampak yang besar pada sektor ekonomi dan sosial. Jenis usaha yang dibuka setiap hari pada kala itu, kini sebagian pedagang lebih memilih untuk menutup usaha mereka dan mereka lebih memilih berjualan pada hari libur saja, seperti usaha kolam renang dan rumah makan kuliner yang rentan terkena abrasi.

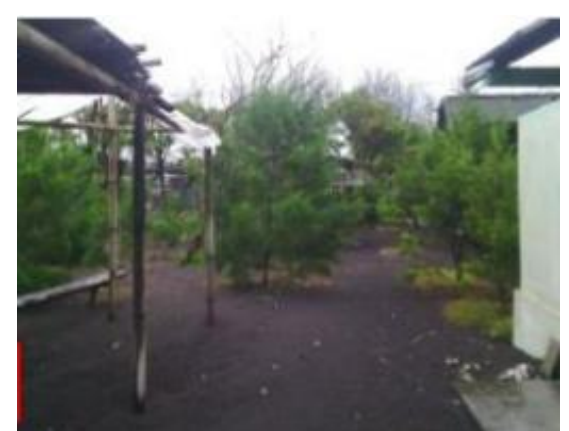

(a)

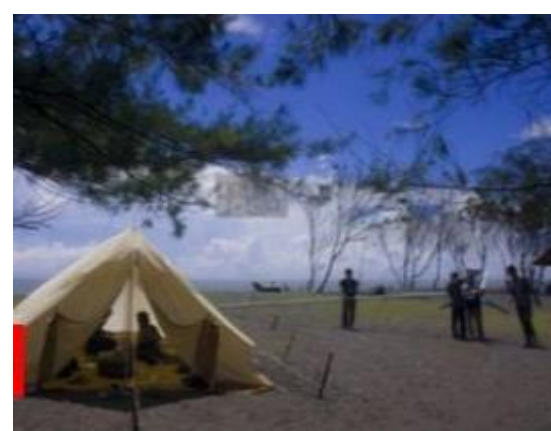

(b)

\section{Gambar 3. Kondisi Pohon Cemara Udang di Pantai Kuwaru (a) Sebelum Penebangan (b) Setelah Penenbangan}

Pada awal mula dibukanya Pantai Kuwaru tahun 2006, keberadaan Pantai Kuwaru dapat memberikan kontribusi pada pendapatan daerah dan berkontribusi terbesar kedua setelah Pantai Parangtritis. Namun pada tahun 2011, kondisi Pantai Kuwaru menurun drastis akibat kerusakan lingkungan yang berdampak pada lingkungan sosial dan ekonomi. Hasil wawancara menunjukkan bahwa jumlah wisatawan yang berkunjung ke Pantai Kuwaru mengalami penurunan akibat kondisi pantai yang kurang menarik minat wisatawan karena kondisinya yang panas dan gersang. Kondisi ini berdampak pada hilangnya mata pencaharian sebagai masyarakat yang membuka jasa dan usaha untuk menunjang sektor pariwisata pantai.

Dari permasalahan tersebut dapat dipahami bahwa perubahan-perubahan yang terjadi pada masyarakat di pantai merupakan konsekuensi dari kegiatan penebangan pohon di kawasan pesisir hingga akhirnya berdampak pada kondisi lingkungan, sosial dan ekonomi. Secara konseptual, perubahan-perubahan yang terjadi merupakan akibat munculnya karena proses akulturasi antara perilaku masyarakat sekitar Pantai Kuwaru dengan perilaku luar dari masyarakat Pantai Kuwaru. Dalam proses inilah terjadi saling mempengaruhi antara budaya masyarakat sekitar objek wisata dengan budaya wisatawan. Di dalam proses pengaruh mempengaruhi antara kedua macam kebudayaan yang berbeda itu tampak suatu gejala bahwa orang-orang di sekitar objek wisata dalam perilakunya apat menggunakan sistem penilaian yang berbeda menurut lingkungan sosialnya (Selo, 2009).

Perilaku masyarakat di Pantai Kuwaru dapat dipengaruhi oleh aspek lingkungan dan akhirnya akan mengubah kehidupan sosial dan ekonomi. Ini dikarenakan perubahan perilaku merupakan faktor internal langsung dari masyarakat sendiri dan berdampak langsung pada kehidupan masyarakat di Pantai Kuwaru. Adapun pengaruh perubahan perilaku terhadap aspek ekonomi masyarakat di Pantai Kuwaru, yaitu menurunnya pendapatan masyarakat di Pantai Kuwaru dan menurunnya jumlah penjualan kuliner seafood di Pantai Kuwaru diakibatkan wisatawan yang berkunjung ke Pantai Kuwaru 
menurun. Sementara itu, pengaruh faktor perilaku pengaruh terhadap aspek sosial, yaitu tingkat pendidikan di Pantai Kuwaru masih rendah sehingga dapat menurunkan kesejahtraan masyarakat di Pantai Kuwaru.

Pantai Kuwaru memiliki potensi destinasi atau atraksi wisata yang menarik. Namun, perilaku pengunjung dan masyarakat yang kurang selaras dengan alam menyebabkan kerusakan lingkungan. Di sisi lain, tingkat pendidikan yang berpengaruh terhadap pengetahuan masyarakat mengenai manfaat pohon cemara udang menyebabkan penebangan pohon untuk dijadikan tambak-tambak udang dan menganggu keseimbangan lingkungan. Temuan ini sejalan dengan temuan penelitian sebelumnya, seperti Hiariey dan Romeon (2013), Primyastanto, Dewi, dan Susilo (2010), serta Harris (2006) yang mengungkapkan bahwa kondisi lingkungan berkorelasi dengan tingkat pendidikan dan pengetahuan masyarakat. Untuk itu, dapat dikatakan bahwa perilaku aktor dalam aktivitas pariwisata pesisir berpengaruh pada kondisi lingkungan. Jika dikaitkan dengan pendapat Bengen (2002) mengenai karakteristik masyarakat pesisir bahwa kondisi masyarakat pesisir dipengaruhi ketergantungan masyarakat pada lingkungan serta tingkat pendidikan dan akhirnya berdampak pada aktivitas ekonomi dan tingkat kesejahteraan masyarakat.

\section{Upaya Penyelematan Pantai Kuwaru dari Kerusakan Lingkungan}

Dalam upaya penyelamatan Pantai Kuwaru dari kerusakan lingkungan telah terdapat beberapa upaya yang dilakukan masyarakat lokal Kuwaru melalui penghijauan kembali pesisir pantai yang terkena dampak abrasi. Kegiatan penghijauan dilakukan oleh kelompok nelayan di Pantai Kuwaru dan bekerja sama dengan pemerintah Kabupaten Bantul. Pemerintah menyiapkan bibit pohon cemara udang dan kelompok nelayan yang melakukan penanaman dan pencangkokan pohon cemara yang masih hidup untuk ditanam kembali.mengcangkok pohon cemara yang masih hidup untuk menanam kembali. Beberapa upaya lain juga sedang dilakukan pemerintah, seperti rencana pembuatan talud atau pemecah ombak di Pantai Kuwaru. Tabel 1 berikut menyajikan ringkasan perilaku yang merusak lingkungan Pantai Kuwaru serta upaya yang sedang dan telah dilakukan untuk menyelamatkan kondisi lingkungan Pantai Kuwaru.

Tabel 1. Perilaku Masyarakat yang Menyebabkan Kerusakan Lingkungan Pantai Kuwaru dan Upaya Penyelamatan Kerusakan Lingkungan Pantai Kuwaru

\begin{tabular}{|c|c|c|c|}
\hline \multirow{2}{*}{ No } & \multirow{2}{*}{ Perilaku } & \multicolumn{2}{|c|}{ Persepsi } \\
\hline & & Pemerintah & Masyarakat \\
\hline 1. & $\begin{array}{l}\text { Penebangan pohon } \\
\text { cemara udang, } \\
\text { akasia dan laresidi }\end{array}$ & $\begin{array}{l}\text { Pemerintah melarang } \\
\text { penebangan pohon cemara } \\
\text { udang, akasia, dan bakau } \\
\text { - Pemerintah bekerja sama } \\
\text { dengan pihak lain untuk } \\
\text { menanam kembali pohon } \\
\text { yang telah ditebang. } \\
\text { - Pemerintah memberikan } \\
\text { bibit untuk penghijauan } \\
\text { kembali di Pantai Kuwaru. }\end{array}$ & $\begin{array}{l}\text { - Masyarakat telah menebang } \\
\text { pohon untuk usaha tambak udang. } \\
\text { - Kelompok nelayan telah } \\
\text { melakukan penghijauan kembali } \\
\text { di Pantai Kuwaru. } \\
\text { - Masyarakat masih menunggu } \\
\text { bibit tanaman dari pemerintah. }\end{array}$ \\
\hline 2. & Tambak Udang & $\begin{array}{l}\text { Pemerintah memberikan izin } \\
\text { kepada PT. INDOKOOR untuk } \\
\text { membuat tambak udang. } \\
\text { Pemerintah memberikan jangka } \\
\text { waktu bagi masyarakat untuk } \\
\text { segera menurup tambak udang. }\end{array}$ & $\begin{array}{l}\text { Masyarakat mengklaim } \text { PT. } \\
\text { INDOKOOR tidak memiliki izin } \\
\text { mendirikan tambak udang. Izin baru } \\
\text { diberikan beberapa saat kemudian } \\
\text { setelah ada komplain dari warga. }\end{array}$ \\
\hline
\end{tabular}


Salah satu cara yang perlu dilakukan mengajak seluruh pihak termasuk masyarakat untuk bersama-sama menjaga lingkungan pesisir. Langkah pemberdayaan masyarakat guna memunculkan kesadaran perlu diberikan karena akan menjamin terciptanya pengelolaan lingkungan yang lebih efektif dan berkelanjutan (Fitriansah, 2012). Langkah konservasi pesisir dengan melibatkan masyarakat merupakan kunci keberhasilan pelestarian pesisir yang berkelanjutan yang dapat memberi manfaat ekonomis bagi masyarakat dan pemerintah daerah (Wardhani, 2011).

\section{Stakeholders Mapping}

Berdasarkan kekuatan, posisi penting, dan pengaruh stakeholder terhadap suatu masalah, stakeholder dapat dikategorikan dalam beberapa kelompok, yaitu stakeholder primer, sekunder dan stakeholder kunci. Berikut adalah penjelasan kedudukan dan fungsi masing-masing stakeholder (Buckles,1999):

a. Stakeholder Primer

Stakeholder primer merupakan stakeholder yang memiliki kaitan kepentingan secara langsung dengan suatu kebijakan, program dan proyek. Mereka harus ditempatkan sebagai penentu utama dalam proses pengambilan keputusan.

Dalam penelitian yang dilakukan, stakeholder primer adalah pemerintah Kabupaten Bantul melalui Dinas Pariwisata Kabupaten Bantul. Dinas Pariwisata Kabupaten Bantul memiliki kepentingan langsung pada wilayah pesisir untuk melarang masyarakat di Pantai Kuwaru tidak menebang pohon cemara udang dan membuka tamabak udang. Pemerintah juga mempunyai rencana untuk menutup semua tambak yang tidak memiliki izin usaha tambak udang.

b. Stakeholder Sekunder

Stakeholder sekunder adalah stakeholder yang tidak memiliki kaitan kepentingan secara langsung terhadap suatu kebijakan, program, dan proyek pemerintah (publik), tetapi memiliki kepedulian dan keprihatinan sehingga mereka turut bersuara dan berpengaruh terhadap keputusan legal pemerintah.

Dalam penelitian yang dilakukan, stakeholder sekunder adalah kepala dukuh di Dusun Kuwaru yang memiliki kepentingan langsung dengan kegiatan yang ada di Pantai Kuwaru. Pihak akademisi juga tergolong dalam stakeholder sekunder dimana akademisi mendorong untuk ditanamnya pohon cemara udang yang ditanami di pesisir Pantai Kuwaru sehingga bisa menjadi daya tarik untuk wisatawan.

c. Stakeholder Kunci

Stakeholder kunci merupakan stakeholder yang memiliki kewenangan secara legal dalam hal pengambilan keputusan. Dalam hal ini, masyarakat lokal Kuwaru adalah stakeholder kunci dimana perilaku masyarakat akan sangat mempengaruhi kondisi wilayah pesisir Pantai Kuwaru.

\section{Kesimpulan dan Rekomendasi}

\section{Kesimpulan}

Pantai Kuwaru memiliki potensi alam berupa pohon cemara udang yang menarik minat wisatawan untuk berkunjung. Namun, perilaku masyarakat sekitar yang buruk, yaitu penebangan pohon cemara udang untuk tambak udang telah merusak kondisi lingkungan pesisir Pantai Kuwaru. Hal ini dilatarbelakangi oleh faktor ekonomi dan faktor sosial berupa tingkat pendidikan masyarakat yang rendah dan upaya peningkatan pendapatan. Hal tersebut mengancam keberlanjutan kawasan dan masyarakat Pantai Kuwaru dalam segi ekonomi, sosial, dan lingkungan. Di samping itu, hilangnya ekosistem pohon cemara udang 
juga berdampak pada meningkatnya abrasi di sekitar pantai sehingga menurunkan pendapatan masyarakat yang bergelut di bidang jasa pariwisata. Hal ini menunjukkan bahwa perilaku manusia berpengaruh terhadap kondisi lingkungan. Aktivitas pariwisata pesisir tanpa standar yang tegas berpeluang menyebabkan dampak kerusakan lingkungan yang besar.

\section{Rekomendasi}

Dalam meminimalisir kerusaka lingkungan di Pantai Kuwaru, diperlukan integrasi peran dan kerjasama pemerintah, nelayan dan masyarakat di pesisir Pantai Kuwaru. Di sisi lain, diperlukan pula ketegasan pemerintah dalam menangani permasalahan yang terjadi di Pantai Kuwaru. Berikut adalah rekomendasi yang diberikan:

1. Melakukan penataan kembali tambak udang yang tidak berizin di Pantai Kuwaru agar pantai Kuwaru memiliki daya saing dengan pantai lain serta dapat menarik minat wisatawan untuk berkunjung.

2. Melakukan penghijauan melalui penanaman kembali pohon cemara udang guna mengurangi kerusakan lingkungan akibat abrasi.

3. Diperlukan peran tokoh masyarakat sebagai penghubung aspirasi masyarakat dengan pemerintah.

4. Memberikan batasan kegiatan tambak udang yang dapat dilakukan di pesisir Pantai Kuwaru, baik oleh masyarakat setempat maupun pengusaha tambak.

\section{Daftar Pustaka}

Arifin, S. (2005). Strategi untuk mengurangi kerusakan lingkungan yang diakibatkan oleh gempa dan gelombang tsunami. Jurnal Arsitektur “ATRIUM”, 2(1), 28-33.

Bengen, D. (2002). Pedoman teknis pengenalan dan pengelolaan ekosistem mangrove. Bogor: Pusat Kajian Sumberdaya Pesisir dan Kelautan, IPB.

Buckles, D. (1999). Cultivating peace, conflict and collaboration in natural resource management. Washington DC USA: WBI.

Fitriansah, H. (2012). Keberlanjutan pengelolaan lingkungan pesisir melalui pemberdayaan masyarakat di Desa Kwala Lama Kabupaten Serdang Bedagai. Jurnal Pembangunan Wilayah \& Kota, 8(4), 360-370.

Gumilar, I. (2012). Partisipasi masyarakat pesisir dalam pengelolaan eksosistem hutan mangrove berkelanjutan di Kabupaten Indramayu. Jurnal Akuatika, 3(2), 198-211.

Hall, C. M. (2001). Trends in ocean and coastal tourism: the end of the last frontier? Ocean \& Coastal Management, 44(9-10), 601-618. doi:10.1016/S0964-5691(01)00071-0.

Hastuti. (2012). Wilayah pesisir dan fenomena-fenomena yang terjadi di pantai. Makassar: Universitas Hassanudin.

Harris, P. G. (2006). Environmental perspectives and behavior in China: Synopsis and bibliography. Environment and Behavior, 38(1), 5-21. doi:10.1177/0013916505280087.

Heddy, S. A. (1994). Antropologi ekologi: Beberapa teori dan perkembangannya. Yogyakarta: Universitas Gajah Mada.

Hiariey, L. S., \& Romeon, N. R. (2013). Peran Serta Masyarakat Pemanfaat Pesisir dalam Rangka Pengelolaan Wilayah Pesisir Teluk Ambon Dalam. Jurnal Matematika, Sains, dan Teknologi, 14(1), 48-61.

Primyastanto, M., Dewi R. P., \& Susilo, E. (2010). Perilaku perusakan lingkungan masyarakat pesisir dalam perspektif Islam (Studi kasus pada nelayan dan pedagang ikan Kawasan Pantai Tambak, Desa Tambakrejo, Kecamatan Wonotirto, Kabupaten Blitar Jawa Timur). Jurnal Pembangunan dan Alam Lestari, 1(1), 1-11.

Rabbany, M. G., Afrin, S., Rahman, A., Islam, F., \& Hoque, F. (2013). Environmental effects of tourism. American Journal of Environment, Energy and Power Research, 1(7), 117-130. 


\section{Kajian Perilaku Masyarakat Pesisir yang Mengakibatkan Kerusakan Lingkungan...}

Selo, S. (2009). Perubahan sosial di Yogyakarta. Jakarta: Penerbit Komunitas Bambu.

Shafei, F., \& Mohamed, B. (2012). Tourism and the enviornment: Issues of concern and sustainability of Southern Part of the Caspian Sea Coastal Areas. Journal of Sustainable Development, 5(3), 2-15. doi:10.5539/jsd.v5n3p2.

Sugiyono. (2012). Metode penelitian kualitatif dan kuantitatif dan R\&D. Bandung: Alfabeta.

Vatria, B. (2010). Berbagai kegiatan manusia yang dapat menyebabkan terjadinya degradasi ekosistem pantai serta dampak yang ditimbulkannya. Jurnal Berlian, $9(1), 47-54$.

Walpole, M. J., \& Goodwin, H. J. (2001). Local attitudes towards conservation and Tourism around Komodo National Park, Indonesia, Environmental Conservation, 28(2), 160-166. doi:10.1017/s0376892901000169.

Wardhani, M. K. (2011). Kawasan konservasi mangrove: Suatu potensi ekowisata. Jurnal Kelautan, 4(1), 60-76.

Zahedi, S. (2008). Tourism impact on coastal environment. WIT Transactions on The Built Environment, 99, 45-57. doi:10.2495/CENV080051.

Zamlawi. (1997). Etika Lingkungan dalam pembangunan berkelanjutan. Jakarta: Direktorat Pendidikan Tinggi, Departemen Pendidikan\& Kebudayaan. 